\title{
Antimicrobial Peptides from Lactobacillus plantarum UTNGt2 Prevent Harmful Bacteria Growth on Fresh Tomatoes
}

\author{
Gabriela N. Tenea* and Tatiana Delgado Pozo \\ Biofood and Nutraceutics Research and Development Group; Faculty of Engineering in Agricultural and Environmental Sciences, Technical \\ University of the North, Barrio El Olivo, 199 Ibarra, Ecuador
}

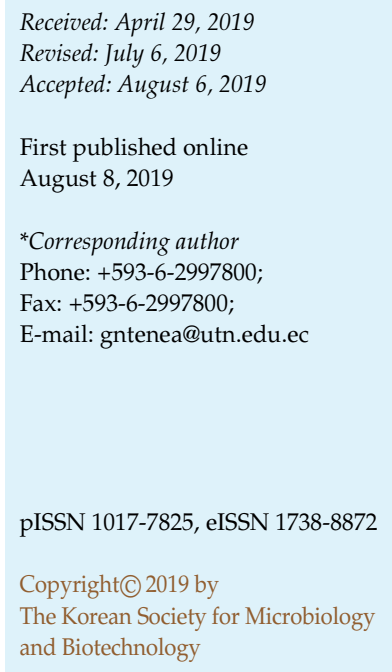

\begin{abstract}
In a previous study, the antimicrobial peptides extracted from Lactobacillus plantarum UTNGt2 of wild-type fruits of Theobroma grandiflorum (Amazon) were characterized. This study aimed to investigate the antimicrobial mechanisms of peptides in vitro and its protective effect on fresh tomatoes. The addition of partially purified Gt2 peptides to the E. coli suspension cells at the exponential $\left(\mathrm{OD}_{605}=0.7\right)$ growth phase resulted in a decrease with $1.67(\log 10)$ order of magnitude compared to the control without peptide. A marginal event $(<1 \log 10$ difference) was recorded against Salmonella, while no effect was observed when combined with EDTA, suggesting that the presence of a chelating agent interfered with the antimicrobial activity. The Gt2 peptides disrupted the membrane of E. coli, causing the release of $\beta$-galactosidase and leakage of DNA/RNA molecules followed by cell death, revealing a bacteriolytic mode of action. The tomatoes fruits coated with Gt2 peptides showed growth inhibition of the artificially inoculated Salmonella cocktail, demonstrating their preservative potential.
\end{abstract}

Keywords: Antimicrobial peptides, plantaricin W, preservation, tomatoes, bacteriolytic

\section{Introduction}

Foodborne diseases are a growing public health problem worldwide, particularly for infants, children and the elderly. Despite advances in food safety, each year more than 9 million people develop illnesses caused by food contamination [1]. A recent report indicated that salmonellosis and campylobacteriosis are the most commonly foodborne diseases within the European region [2]. In Ecuador (2001), the Ministry of Public Health reported 311,401 cases of infections with Salmonella and Shigella, while the number doubled in 2017 [3]. At the local facilities, artisanal fresh and minimally processed food products are stored in defective conditions or incorrectly manipulated, therefore, the risk of contamination is significant [4]. It might be a cultural phenomenon as no improvement of selling sites has been undertaken. Consequently, the attention of policymakers was assumed to increase control, prevention and consumer protection by improving communication regarding food safety among producers, packers, processors and distributors and by facilitating relevant research on food preservation. A recent investigation in Brazil suggested the need for continuous training of vendors [5]. Commonly, chemical and physical preservation protocols are used to control the presence of pathogenic or spoilage bacteria in food, nonetheless, the application of natural methods for preservation remains underdeveloped.

Lactic acid bacteria (LAB) have attracted significant attention to the food industry due to their GRAS (Generally Regarded as Safe) status [6]. Antimicrobial substances (bacteriocins and organic acids) produced by several LAB strains have been proven to be effective in controlling growth of microorganisms in several food products [7-10]. Thus, their incorporation in food has become an area of dynamic research in the last decade [9, 11, 12]. A large arsenal of bacteriocins with different properties, target species, and producer organisms has been characterized [13]. The majority of bacteriocins belong to class I and II, are active in the nanomolar range, and cause membrane permeabilization leading to the dissipation of membrane potential, the leakage of ions, ATP, as well as DNA/RNA 
molecules from the target bacteria [14].

Recently, we reported a Lactobacillus plantarum Gt2 strain producing peptides having similarity with plantaricin $\mathrm{W}$ alpha and beta precursors showing stable inhibitory activity at a high temperature range $\left(60-121^{\circ} \mathrm{C}\right)$, wide $\mathrm{pH}$ range (2-10), and positively activated by several ionic and anionic compounds [4]. Nonetheless, the actual mechanism by which partially purified Gt2 peptides target Gramnegative bacteria remains unknown. The aim of this research was to determine how these peptides act against some commensal ubiquitous food microorganisms (Salmonella and E. coli) and to evaluate their protective effect on postharvest fresh tomatoes for further use as natural preservatives.

\section{Materials and Methods}

\section{Bacterial Strains}

Lactobacillus plantarum UTNGt2 (GenBank Accession No. KY041688.1) was isolated from tropical wild-type fruits of Theobroma grandiflorum (copoasu or white coffee) collected from the Sucumbíos Province, in the Amazon region of Ecuador. A bacteriocin producer strain Lactobacillus plantarum ATCC 8014 (LP) was used as a standard [15]. The indicator strains were: E. coli ATCC 25922, Salmonella enterica subsp. enterica ATCC 51741.

\section{Partially Purified Peptide Preparation}

The partially purified peptides from both Gt2 and LP strains were obtained as previously described [4]. Briefly, the Gt2 and LP strains grown in MRS broth at $37^{\circ} \mathrm{C}$ for $24 \mathrm{~h}$ were used to extract cell free supernatant (CFS) by centrifugation at 13,000 $\times \mathrm{g}$ for $30 \mathrm{~min}\left(4^{\circ} \mathrm{C}\right)$. The CFS was filtered using a $0.22 \mu \mathrm{m}$ porosity syringe filter (\# STF020025H, ChemLab Group, USA). Then, $60 \%$ ammonium sulfate was added to CFS, incubated overnight with refrigeration without stirring and centrifuged at $8,000 \times g$ for 30 $\min$ at $4^{\circ} \mathrm{C}$. The peptides were recovered in $25 \mathrm{mM}$ ammonium acetate ( $\mathrm{pH}$ 6.5), desalted by using a Midi Dialysis Kit (Cat. \# PURD10005-1KT, Sigma-Aldrich, USA) pre-equilibrated with phosphate buffer $(\mathrm{pH} 7.0)$ and stored at $-20^{\circ} \mathrm{C}$ before use. Titer estimated as au $\mathrm{ml}^{-1}$ is defined as the highest dilution that inhibited the growth of the indicator strain. Antimicrobial activity was analyzed using the agar-well diffusion method [4].

\section{Effect of Gt2 Peptides on Indicator Cell Viability}

The indicator bacteria E. coli ATCC 25922 and Salmonella enterica ATCC 51741 were grown independently in tubes containing LB (Luria Bertani, Difco) and nutrient broth medium (Difco). The peptides at the final concentration 1 MIC [16] were added to the indicator strain culture $(100 \mathrm{ml})$ at the exponential growth phase $\left(\mathrm{OD}_{605}=0.7\right)$ followed by incubation at $37^{\circ} \mathrm{C}$ for $6 \mathrm{~h}$ using the plate-agar method to determine the viable cell counts at given incubation time intervals. In independent experiments, the effect of EDTA on Gt2 activity was evaluated [16]. The results were presented as $\log 10$ reductions, calculated as the difference between $\log 10$ (CFU) of the untreated cells (no bacteriocin, no EDTA) and the treated cells (bacteriocin added, EDTA or a combination thereof). A $\log 10$ reduction of $<1$ was considered insignificant. The experiments were repeated three times and untreated indicator strain cultures were used as controls.

\section{Cell Membrane Integrity Assay}

If the bacterial membrane of the target cells is compromised, the cellular components (DNA/RNA molecules) can be released and detected by measuring the absorbance at $260 \mathrm{~nm}$ [17]. The indicator bacterial suspensions (E. coli and Salmonella) were grown overnight in appropriate broth culture media, harvested by centrifugation and washed twice with $1 \times$ PBS (phosphate-buffered saline, $\mathrm{pH} 7.5)$. The bacterial cells were treated independently with peptides Gt2 (1 MIC), peptides LP (1 MIC) and nisin from Lactococcus lactis 2.5\% (\# N5764, Sigma) $(50 \mu \mathrm{g} / \mathrm{ml})$ and incubated at $30^{\circ} \mathrm{C}$. One flask was maintained as control (no peptides). Cell cultures were centrifuged after one hour incubation, the supernatant filtered, while optical density was measured using a spectrophotometer (Nova60, Millipore, Merck). Subsequently, the supernatant was precipitated with isopropanol and ammonium acetate (3M), washed with 75\% ethanol, followed by electrophoresis in $1 \%$ agarose gel with ethidium bromide, running in $1 \times \mathrm{TBE}$ (Tris-borate EDTA, pH 8.0) buffer (Sigma) to detect released DNA/RNA molecules.

\section{Cytoplasmic Membrane Permeabilization}

The $E$. coli cytoplasmic membrane permeabilization by peptides of Gt2, LP (1 MIC final concentration) and nisin $(50 \mu \mathrm{g} / \mathrm{ml})$ were investigated using ONPG (o-nitro-phenyl-L-D-galactoside, \# N1127, Sigma, USA) as substrate [17]. Briefly, bacteria cells grown to logarithmic phase in LB (Luria Bertani, Difco) medium containing $2 \%$ lactose were collected and washed twice with $10 \mathrm{mM}$ sodium phosphate buffer ( $\mathrm{pH} 7.5)$ and $100 \mathrm{mM} \mathrm{NaCl}$. The Gt2 and LP peptides and nisin were added to the bacterial suspension at optical density 0.6 , incubated $5 \mathrm{~min}$ at $30^{\circ} \mathrm{C}$, then ONPG with a final concentration of $30 \mathrm{mM}$ was added to each cell suspension. The hydrolysis of ONPG to O-nitrophenol (ONP) over time (120 min) was monitored at $420 \mathrm{~nm}$. To distinguish between the cytoplasmic enzyme release and peptide uptake to the cells, the bacteria were removed by centrifugation for $120 \mathrm{~min}$ and the supernatant was used to measure the $\beta$-galactosidase release. The release was quantified as production of o-nitrophenol $(\mathrm{ONP})$ at $\mathrm{ml} / \mathrm{min}$ and calculated as described: [A415 × 1,000/ sample volume $(\mu \mathrm{l})] /$ reaction time $(\mathrm{min}) \times 4.86$; where A415 was the absorbance at $415 \mathrm{~nm}$ and 4.86 was the coefficient of extinction $\left(\mathrm{mM}^{-1} \mathrm{~cm}^{-1}\right)$ of ONP respectively [17].

\section{Effect of Gt2 Peptides on Whole Cell Protein Profile of Target E. coli Cells}

The whole cell protein profile of E. coli after the treatment with 
Gt2 peptides was analyzed using SDS-PAGE method [18]. Overnight cultures of E. coli were centrifuged at 3,000 rpm, washed twice with $1 \times$ PBS buffer $(\mathrm{pH} 7.4)$; the cells' pellet was suspended in $1 \times$ SDS-PAGE loading buffer, boiled for $5 \mathrm{~min}$ at $100^{\circ} \mathrm{C}$ and centrifuged at $300 \mathrm{rpm}$. The supernatants of treated and non-treated E. coli were used in SDS-PAGE electrophoresis. The tricine-SDS-PAGE method using pre-casted acrylamide gels $(12 \%)$ and a Thermo Fisher OWL $(10 \times 10)$ vertical electrophoresis system was used. The gel was stained with Takara CBB Safe Stain (Cat. \# T9320A, Takara, Bio Company, Japan) for $4 \mathrm{~h}$ and distained with a solution of $30 \%$ methanol (v/v) and glacial acetic acid, $10 \%$ $(\mathrm{v} / \mathrm{v})$ until the bands became clear.

\section{Inhibitory Effect of Gt2 Peptides on Tomatoes during Storage}

Tomatoes chosen at stage four according to the color chart of tomato ripening (USDA standards) were purchased from a local vender, washed with $5 \%$ bleach solution for $5 \mathrm{~min}$, then twice with distilled water and left to dry in a laminar flow cabinet before inoculation with the pathogen cocktail. The inoculation was performed with a mixture of Salmonella enterica subsp. enterica ATCC 51741 and Salmonella UTNSm2 (lab collection isolated from contaminated local food). Tomatoes (3 per treatment) were submerged in $200 \mathrm{ml}$ of bacterial inoculum cocktail $\left(10^{8} \mathrm{CFU} / \mathrm{ml}\right)$ and rotated by stirring with a glove-covered hand for $10 \mathrm{~min}$ to ensure that bacteria penetrated the fruits; followed by air drying for 1 day in a biosafety cabinet. The tomatoes were washed as follows: a) the fruits were individually immersed in peptide Gt2 (1 MIC) solution; b) immersed in peptide LP (1 MIC) solution; c) nisin $(50 \mu \mathrm{g} / \mathrm{ml})$; in a total volume of $200 \mathrm{ml}$, manually rotating each fruit for $5 \mathrm{~min}$ to assure complete coverage and contact of surfaces with the wash solution, and then left to dry overnight under the biosafety cabinet. The fruits were packed in trays covered with plastic alimentary film then stored for 14 days with refrigeration. The tomatoes washed with sterile water, no peptides added, no Salmonella (control 1) and tomatoes inoculated with bacterial cocktail but not peptides (control 2) were used as control. At different time intervals (1, 7, and 14 days) the viability of inoculated bacteria was evaluated using the agar plate method [16]. The effect of peptides on hampering the rottenness and fungi forming on tomatoes was evaluated after the treatment with Gt2, LP peptides and nisin, without inoculating with Salmonella during storage (23 days). Tomato samples (3 samples per treatment) without any treatment were used as control. Treated and nontreated samples were stored at either room temperature $\left(18^{\circ} \mathrm{C}\right)$ or were refrigerated $\left(5^{\circ} \mathrm{C}\right)$. The experiment was repeated three times using tomatoes monthly purchased from the same distributer.

\section{Statistical Analysis}

All experiments were performed in triplicate; three independent experiments repeated and the results were expressed as mean \pm standard deviation. Analysis of variance was applied with Tukey to determine the significant differences between the means (SPSS version 15.0).

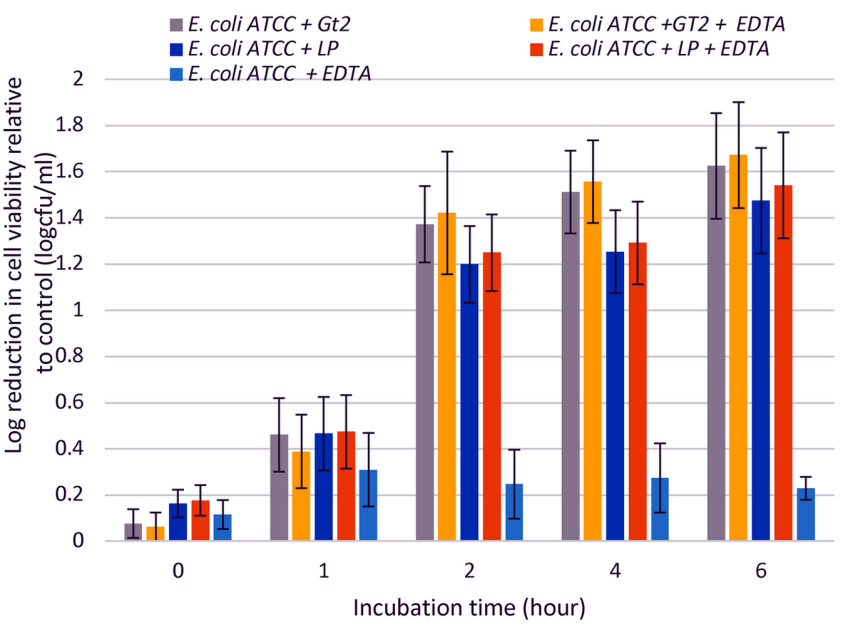

Fig. 1. Effect of the G2 Strain with and without EDTA on E. coli ATCC 25922 cell density.

Bars represent $\log 10$ reduction calculated as difference between cells with and without bacteriocin; $\log 10$ reductions $<1$ were considered insignificant.

\section{Results and Discussion}

\section{Peptides from Gt2 Strain Diminished Target Cell Viability}

The initial cell density of E. coli was $6.05 \log 10 \mathrm{CFU} / \mathrm{ml}$ at the inoculation time with the peptides. The addition of Gt2 peptides resulted in a significant $(p<0.05)$ decrease of cell viability with $1.62 \log 10$ relative to the control in the absence of the peptide (Fig. 1). Similarly, the addition of LP peptides resulted in a $1.47 \log 10$ reduction. Early studies have demonstrated that some bacteriocins are inactive against Gram-negative bacteria if not combined with chemical or physical treatments that disrupt the outer membrane [19]. For example, the L. monocytogenes cell viability reduction was recorded when nisin was combined with EDTA or nisin-sodium-diacetate-EDTA [20, 21]. In the present study, about the same level of cell reduction $(1.67 \log 10 \mathrm{CFU} / \mathrm{ml})$ was achieved when Gt2 peptides were co-treated with EDTA, suggesting that the presence of a chemical agent did interfere with its antimicrobial activity. A marginal decrease $(0.86 \log 10$ reduction) of Salmonella cell viability was recorded when Gt2 peptides were added only or in combination with EDTA at $6 \mathrm{~h}$ of incubation while no clear change $(0.23-0.27 \log 10)$ in cell density was registered upon treatment with LP peptides only or combined with EDTA (data not shown). Previously, we showed that EDTA enhanced the inhibitory activity towards Salmonella when combined with peptides produced by another LAB strain [16]. Thus, we suggest that 
the bactericidal effect might depend on the effectiveness of the producer strain and the level of inhibition varies with the target bacteria. In the present study, the Gt2 peptides showed bacteriolytic effect against pathogens without combining them with an extra destabilizing membrane factor, indicating that the inhibitory activity profile does not follow a general trend.

\section{Peptides Produced by the Gt2 Strain Alter the Target Cell Membrane Integrity}

The release of cellular components with strong UV absorption at $260 \mathrm{~nm}$ arises when cells are exposed to drugs (e.g. antibiotics, antimicrobial peptides) as indicators of target membrane damage [17]. When E. coli suspension cells were treated with Gt2 and LP peptides, the optical density increased rapidly after one hour of incubation (data not shown). Moreover, DNA/RNA molecules were detected in agarose gel electrophoresis, indicating that the target bacterial membrane became compromised (Fig. 2). This result was in agreement with the bactericidal mode of action of Gt2 peptides towards E. coli. Earlier studies indicated that some bacteriocins are able to interact with the target bacterial membrane, forming ion channels, leading to the increase of cytoplasmic membrane permeability and hence to death $[12,14,22,23]$. Similar results were obtained when the peptides were added to Salmonella suspension cells, while nisin was underwhelmingly inactive against both E. coli and Salmonella. Previous research indicated that

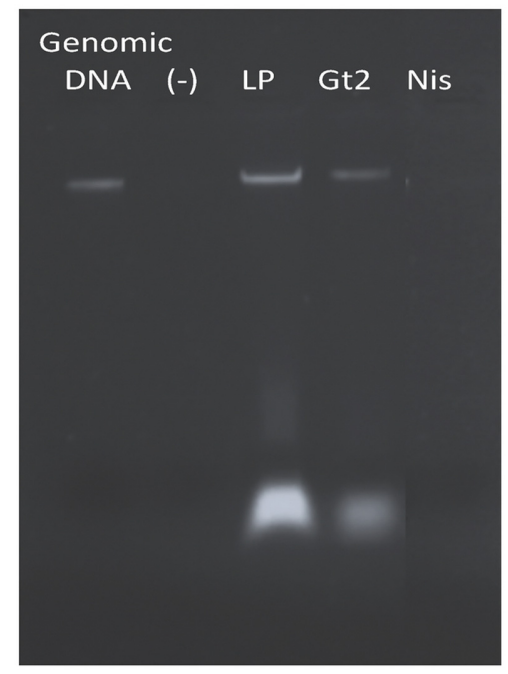

Fig. 2. Detection of DNA/RNA molecules released when Salmonella was treated with the peptides.

Legend: gDNA- genomic DNA from Salmonella enterica subsp. enterica ATCC 51741. (-) negative control (no DNA/RNA molecules); LP, Gt2: treatment with peptides $(1 \mathrm{~h})$; Nis-nisin (Sigma). nisin, a Class I lantibiotic bacteriocin, has marginal inhibitory activity towards Gram-negative bacteria and its effect on membrane permeability is enhanced when it is combined with a chelating agent [24-26]. The Gt2 amino acid sequence deducted from the gene nucleotide sequencing concedes to two-component bacteriocin (twopeptide lantibiotics), plw $\alpha$ and plw $\beta$ of plantaricin $W$ [4], post-transcriptionally modified peptides that work together in one functional inhibitory unit [27]. Although bacteriocins from lactic acid bacteria are smaller peptides, we were in agreement with other authors indicating that the superior inhibitory effect against Gram-negative bacteria might be related with the presence of more than one secreted peptide (e.g. SDS-PAGE analysis showed more than one band corresponding to larger peptides), thus further study is needed to identify the protein fraction(s) responsible for the antimicrobial activity as well as its amino acid composition. The results indicated that Gt2 peptides altered the cellular membrane of target bacteria, leading to the leaching of cytoplasmic molecules followed by cellular death.

\section{Gt2 Peptides Induced Inner Membrane Permeabilization in E. coli}

Generally, cytoplasmic $\beta$-galactosidase cannot pass through the integral bacteria cell membrane unless the inner membrane is compromised. In addition to inhibitory activity, bacteriocins constitute an anti-resistance compound to classic antibiotics as they interact with bacterial membranes, create ion permeable channels leading to increased cytoplasmic permeability, thus resulting in bacterial cell death [28]. The ability of Gt2 peptides to permeate the membrane of $E$. coli was evaluated as a function of cytoplasmic $\beta$-galactosidase release, with bacteria grown in lactose-containing medium. When cells were treated with Gt2 or LP, there was a lag time of $30 \mathrm{~min}$ followed by a progressive release of $\beta$-galactosidase for up to 120 min until reaching a steady state (Fig. 3A). On the other hand, the nisin displayed a marginal effect. No $\beta$ galactosidase activity was detected in culture medium of bacterial cells without peptides. Similarly, the peptide F1 produced by $L$. paracasei increased the membrane permeability of Staphylococcus aureus [14]. Moreover, the results show that the Gt2 peptides caused considerable release of the enzyme into the medium within the incubation time (Fig. 3B). The fact that the enzyme units in cell-free medium were lower than the determined units suggests that Gt2 raised cytoplasmic membrane permeability to ONPG as well as the outward release of the 


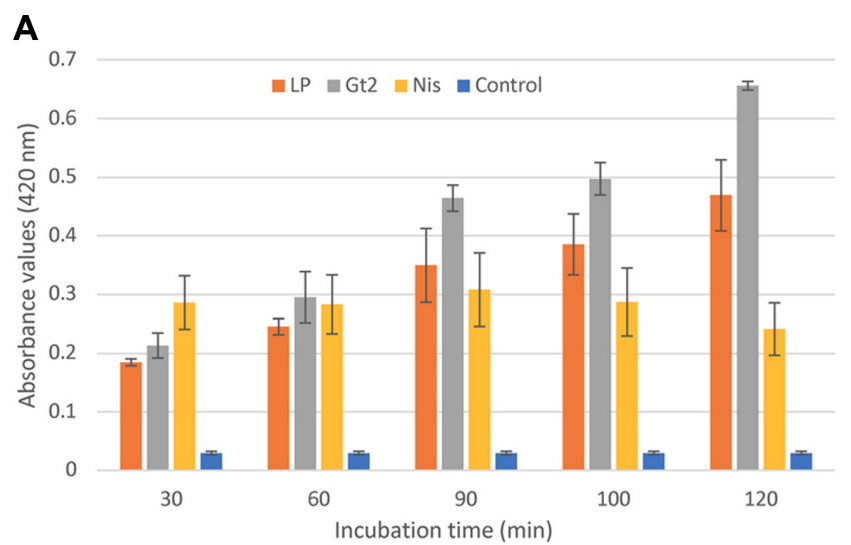

B

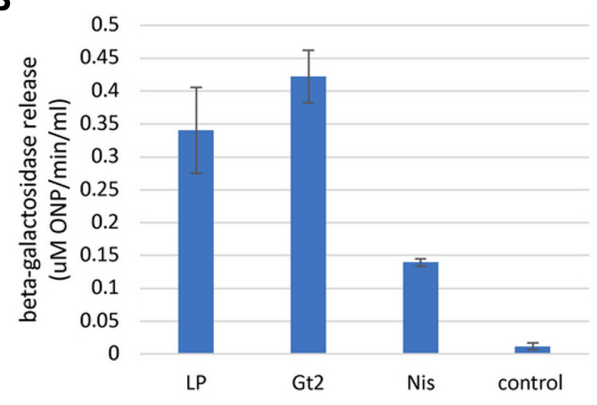

Fig. 3. The cytoplasmic membrane permeation of E. coli ATCC 25922.

(A) Beta-galactosidase activity (measured from the absorbance at $420 \mathrm{~nm}$ ) in the culture medium of E. coli cells treated with Gt2, LP peptides and nisin. Data were expressed as mean \pm standard deviation; (B) beta-galactosidase release. Bacteria (after $120 \mathrm{~min}$ incubation) were removed by centrifugation and enzyme release was assayed in the cell-free supernatant. Legend: LP: peptides produced by L. plantarum ATCC 8014; Gt2: peptides produced by L. plantarum Gt2; Nis: nisin (Sigma); control: E. coli non-treated cells.

enzyme. This result is in concordance with the study of Ibrahim et al. [29]. Additionally, a slightly different protein profile of E. coli untreated and treated with Gt2 peptides was observed in SDS-PAGE analysis (Fig. 4). Although the proteins were not identified, the changes in the expressed one were related with the damaging of the proteins from the cells treated with Gt2 peptides compared to untreated control. Previous investigations of the total protein profile of $E$. coli treated with the synthetic bactericidal agent zinc oxide nanoparticle (ZNP) indicated cytoplasmic membrane damage of the target cells [17].

\section{Protective Effect of Gt2 Peptide-Based Suspension on Tomato Fruits}

Tomato (Lycopersicon esculentum Mill.) is one of the most

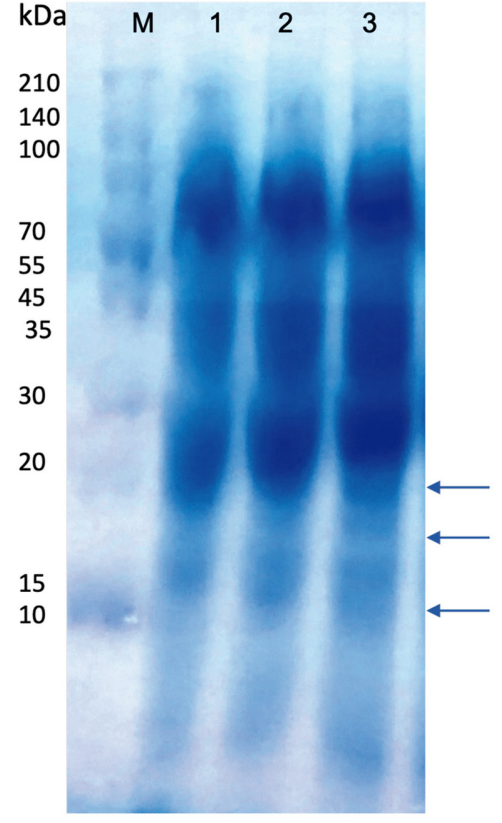

Fig. 4. SDS-PAGE study of E. coli ATCC 25922 whole cell proteins after peptide treatment; Legend: 1: E. coli cells untreated; 2, 3-E. coli cells treated with Gt2 and LP peptides; M: molecular marker (Takara, Japan); arrows indicated different bands.

popular vegetables in Ecuador. The common "tomato riñón" is daily consumed in fresh salads or as garnish for various foods, and is a rich source of vitamin A and other nutrients. Tomatoes are usually consumed at their maximum organoleptic quality which takes place when they reach the full red color stage but before excessive softening. As the fruit contain a large amount of water it is prone to contamination by various microorganisms; recently several cases of illnesses were reported when Roma tomato fruits contaminated with Salmonella ser. Branderup were consumed in a restaurant in Delhi [30]. In this study, the potential of Gt2 peptides to delay or protect the postharvest deterioration of tomato fruits was evaluated. The tomatoes were purchased at the fourth ripening stage according to the USDA standard index [31], which is considered a suitable stage for the treatment, as at stage five or six they rapidly become soft. The initial density of the total inoculated Salmonella cocktail was 5.78 $\log 10 \mathrm{CFU} / \mathrm{g}$ at day 0 before treatment with both partial purified peptides and nisin. A statistically significant decrease of Salmonella population $(p<0.05)$ was registered when tomatoes were treated with either Gt2 or LP peptides (Table 1), while in the control tomatoes (2) the cell count 
Table 1. Survival of Salmonella cells from tomatoes treated with the peptides after storage.

\begin{tabular}{lcccc}
\hline \multirow{2}{*}{ Treatments $^{\text {a }}$} & \multicolumn{4}{c}{ Salmonella population $^{\mathrm{b}}(\log 10 \mathrm{CFU} / \mathrm{g})$} \\
\cline { 2 - 5 } & Day 0 & Day 1 & Day 7 & Day 14 \\
\hline Control 1: Tomato + water & $(-)$ & $(-)$ & $(-)$ & $(+)$ \\
Control 2: Tomato + Salmonella cocktail & $5.78 \pm 0.20^{\mathrm{A}}$ & $5.45 \pm 0.18^{\mathrm{A}}$ & $5.42 \pm 0.12^{\mathrm{A}}$ & $5.30 \pm 0.11^{\mathrm{A}}$ \\
Tomato + Salmonella cocktail +Gt2 peptides & $5.78 \pm 0.20^{\mathrm{A}}$ & $5.43 \pm 0.13^{\mathrm{A}}$ & $4.76 \pm 0.26^{\mathrm{C}}$ & $2.97 \pm 0.22^{\mathrm{D}}$ \\
Tomato + Salmonella cocktail +LP peptides & $5.78 \pm 0.20^{\mathrm{A}}$ & $5.36 \pm 0.10^{\mathrm{A}}$ & $4.86 \pm 0.16^{\mathrm{C}}$ & $3.63 \pm 0.17^{\mathrm{C}}$ \\
Tomato + Salmonella cocktail + nisin & $5.78 \pm 0.20^{\mathrm{A}}$ & $5.39 \pm 0.12^{\mathrm{A}}$ & $5.21 \pm 0.10^{\mathrm{B}}$ & $4.50 \pm 0.18^{\mathrm{B}}$ \\
\hline
\end{tabular}

${ }^{\mathrm{a}}$ Concentrations of antimicrobial agents were $50 \mathrm{mg} / \mathrm{ml}$ nisin and $1 \mathrm{MIC}$ of Gt2 and LP peptides. (-): no bacteria; (+): detection of Salmonella in untreated tomatoes at 14 days of storage.

${ }^{b}$ Values are means \pm standard deviations of three trial experiments. Means in the same column followed by a different capital letter are significantly $(p<0.05)$ different.

was maintained at the same level, indicating that the Salmonella cells were fitting to the fruits' complex composition. Although the Salmonella population did not diminish completely, the $\log 10$ reductions were 2.33 and 1.67 units for Gt2 and LP peptides respectively, at 14 days of storage, suggesting that the peptide/protein-solution might penetrate the tomato surface forming a barrier between the fruit and the environment, improving its safety and consequently its shelf life. These findings, correlated with the in vitro study of mode of action, as the Salmonella cell culture was not completely eliminated upon direct interaction with the peptides. No such reduction was achieved when tomatoes were treated with nisin-solution (0.80 $\log 10$ unit). Unpredictably, at 14 days, the un-treated tomatoes (control 1) showed contamination with Salmonella (Table 1). This might be due to the internal fruit contamination before harvesting. Thus, our results demonstrated that a Gt2 peptide-based suspension was effective against the Salmonella cocktail, and might be a solution to protect the fruits from harmful bacteria during storage. A recent study on fresh whole cantaloupe washed with nisin-EDTA indicated its efficacy to decrease the Salmonella population on day 7 of storage that could lead to both increasing shelf life and reducing the risk of foodborne illness from contamination with Salmonella [32]. If in the cantaloupe study the peptide-solution was used as washing solution, at different intervals, in our experimental study the solution was applied one time only to avoid the deterioration of the fruit during manipulation, considering that tomatoes are more perishable than cantaloupe. It is known that tomatoes are susceptible to spoilage by fungi which can produce mycotoxins that are detrimental to human health [33]. In this study, the first indication of rottenness was observed on day 7 of storage at room temperature in the untreated tomatoes, while the deterioration was delayed by 10 and 7 days in the tomatoes
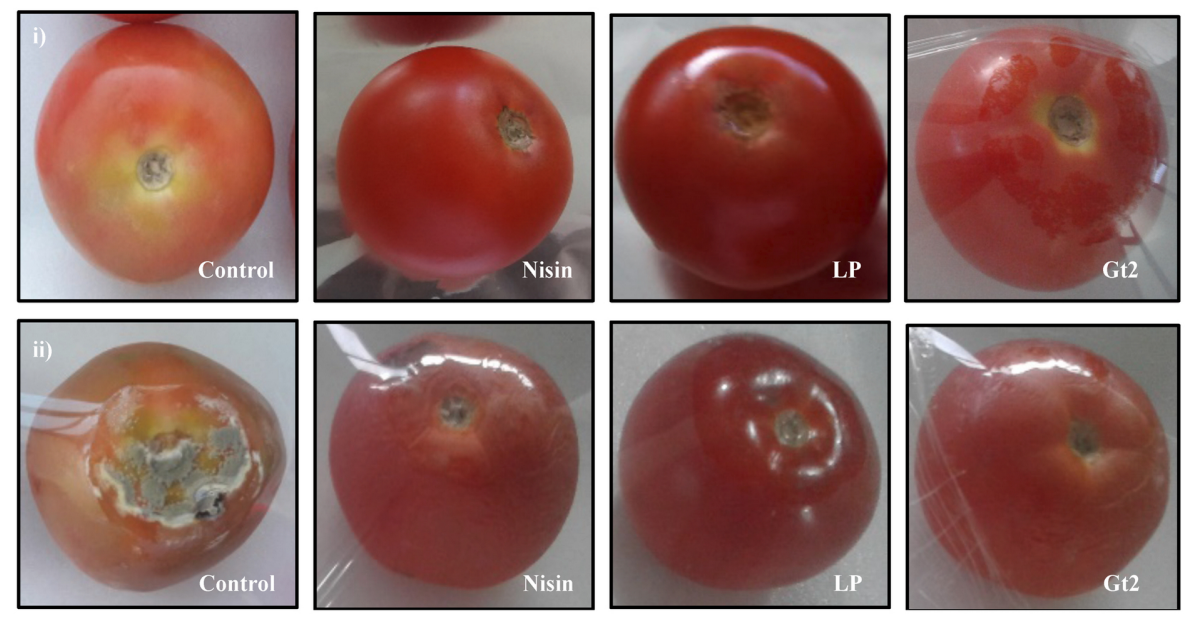

Fig. 5. Protective effect of coated tomatoes with antimicrobial peptide-based suspension at room temperature.

Control: tomato washed with sterile water, no peptides added; Gt2, LP and Nisin: tomatoes inoculated with antimicrobial substances; Gt2, LP, peptides and Nisin, respectively; panel i) day 1; ii) day 17. 
treated with the peptides and nisin, respectively. Fig. 5 shows the tomato fruits on day 1 (panel i) and 17 (panel ii) of storage with the visible signs of spoilage in the control tomatoes. No signs of spoilage were detected in the peptide-treated tomatoes, while the sample treated with nisin showed skin deterioration. Although we do not identify the microorganisms that were responsible with the deterioration of control tomato (untreated with peptides), the filamentous fungi were visible observed, suggesting the possible anti-fungal activity of the Gt2 peptides; further analysis are need it to demonstrate this statement. Samples stored in refrigeration were preserved up to 23 days, when the fruits became softer and showed superficial skin wrinkles, leading to a dry and dull appearance. Early research of tomatoes covered with a food packaging biofilm containing the bacteriocin sonorensin indicated the protective effect of bacteriocin up to day 7 [12]. In the current study the fruits were dipped in the peptide solution, dried for $24 \mathrm{~h}$ to ensure that the fruit membrane was penetrated and covered with the polymer film; thus, we suggest that the retardation of spoilage development was related to the presence of the active components on fruit membranes. Covering or coating the fruit with active peptide-containing washing suspension seems to be a promising approach for active protection, but at this point we don't know the exact concentration of active compound that was adsorbed by the fruit.

Taken together, the Gt2 peptide suspension effectively inhibits both E. coli and Salmonella at the exponential growth phase, demonstrating its bacteriolytic mode of action. The Gt2 peptides are perforating the cytoplasmic membrane disturbing the cell integrity, leading to the release of intracellular molecules and finally to cellular death. Coating the tomato fruits with Gt2 peptide-based suspension proves to be a promising approach to control the spoilage in fresh tomatoes, thus enhancing the safety of food products.

\section{Acknowledgments}

This research work was carried out with the financial support of Technical University of the North, Centre of Research (CUICYT)-Grant no. 2418/2018. The authors wish to thank F. Veintimilla for helping with the experiments.

\section{Conflict of Interest}

The authors have no financial conflicts of interest to declare.

\section{References}

1. Scallan E, Hoekstra RM, Angulo FJ, Tauxe RV, Widdowson M, Roy SL, et al. 2011. Foodborne illness acquired in the United States-major pathogens. Emerg. Infect. Dis. 17: 7-15.

2. EFSA. 2017. The European Union summary report on trends and sources of zoonoses, zoonotic agents and food-borne outbreaks in 2016. Sci. Rep. doi: 10.2903/j.efsa.2017.5077.

3. Pérez Parra J, Useche Castro L, Isea León F, Cuello Pérez M, Canchingre Bone E. 2017. Evaluation of hepatitis A as foodborne disease in Ecuador during 2015. Revista Cumbers 3: $25-32$.

4. Garzón K, Ortega C, Tenea GN. 2017. Characterization of bacteriocin-producing lactic acid bacteria isolated from native fruits of Ecuadorian Amazon". Pol. J. Microbiol. 66: 473-481.

5. Cortese RDM, Veiros MB, Feldman C, Cavalli SB. 2016. Food safety and hygiene practices of vendors during the chain of street food production in Florianopolis, Brazil: a cross-sectional study. Food Control 62: 178-186.

6. Özogul F, Hamed I. 2018. The importance of lactic acid bacteria for the prevention of bacterial growth and their biogenic amines formation: A review. Crit. Rev. Food Sci. Nutr. 58: 1660-1670.

7. Yang SC, Lin CH, Sung CT, Fang JY. 2014. Antibacterial activities of bacteriocins: application in food and pharmaceuticals. Front Microbiol. 5: 241.

8. Backialakshmi S, Meenakshi RN, Saranya A, Jebil MS, Krishna AR, Krishna JS, et al. 2015. Biopreservation of fresh orange juice using antilisterial bacteriocins101 and antilisterial bacteriocin103 purified from Leuconostoc mesenteroides. J. Food Process. Technol. 6: 479.

9. Angmo K, Kumari A, Savitri M, Bhalla TC. 2016. Antagonistic activities of lactic acid bacteria from fermented foods and beverage of Ladakh against Yersinia enterocolitica in refrigerated meat. Food Biosci. 13: 26-31.

10. Rai M, Pandit R, Gaikwad S, Kövics G. 2016. Antimicrobial peptides as natural bio-preservative to enhance the shelf-life of food. J. Food Sci. Technol. 53: 3381-3394.

11. Biscola V, Todorov SD, Capuano VSC, Abriouel H, Gálvez A, Franco BDGM. 2013. Isolation and characterization of a nisin-like bacteriocin produced by a Lactococcus lactis strain isolated from charqui, a Brazilian fermented, salted and dried meat product. Meat Sci. 93: 607-613.

12. Chopra L, Singh G, Kumar JK, Sahoo DK. 2015. Sonorensin: a new bacteriocin with potential of an anti-biofilm agent and a food biopreservative. Sci. Rep. 5: 13412.

13. Cotter PD, Hill C, Ross RP. 2005. Bacteriocins: developing innate immunity for food. Nat. Rev. Microbiol. 3: 777-788.

14. Miao J, Zhou J, Liu G, Chen F, Chen YG, Xiangyang D, et al. 2016. Membrane disruption and DNA binding of Staphylococcus aureus cell induced by a novel antimicrobial peptide produced 
by Lactobacillus paracasei subsp. tolerans FX-6. Food Control 59: 609-613.

15. B Lash BW, Mysliwiec TH, Gourama H. 2005. Detection and partial characterization of a broad-range bacteriocin produced by Lactobacillus plantarum (ATCC 8014). Food Microbiol. 22: 199-204.

16. Tenea GN, Hurtado P, Ortega C. 2018. Inhibitory effect of substances produced by native Lactococcus lactis strains of tropical fruits towards food pathogens. Prev. Nutr. Food Sci. 23: 260-268.

17. Pérez Parra J, Useche Castro L, Isea León F, Cuello Pérez M, Canchingre Bone, E. 2015. Damage of lipopolysaccharides in outer cell membrane and production of ROS-mediated stress within bacteria makes nano zinc oxide a bactericidal agent. Appl. Nanosci. 5: 857-866.

18. Lasserre JP, Beyne E, Pyndiah S, Lapillerie D, Claverol S, Bonneu, M. 2006. A complexomic study of Escherichia coli using two-dimensional blue native/SDS polyacrylamide gel electrophoresis. Electrophoresis 27: 3306-3321.

19. Chalón MC, Acuña L, Morero RD, Minahk CJ, Bellomio A. 2012. Membrane-active bacteriocins to control Salmonella in foods: are they the definite hurdle?. Food Res. Int. 45: 735744.

20. Martin-Visscher LA, Yoganathan S, Sit SC, Lohans CT, Vederas JC. 2011. The activity of bacteriocins from Carnobacterium maltaromaticum UAL307 against Gram-negative bacteria in combination with EDTA treatment. FEMS Microbiol. Lett. 317: 152-159.

21. Bhatia S, Bharti A. 2015. Evaluating the antimicrobial activity of nisin, lysozyme and ethylenediaminetetraacetate incorporated in starch based active food packaging film. J. Food Sci. Technol. 52: 3504-3512.

22. Bajpai VK, Rather IA, Majumder R, Alshammari FH, Nam G, Park Y. 2017. Characterization and antibacterial mode of action of lactic acid bacterium Leuconostoc mesenteroides HJ69 from Kimchi. J. Food Biochem. 41: e12290.
23. Yeaman MR, Yount. NY. 2003. Mechanisms of antimicrobial peptide action and resistance. Pharmacol. Rev. 55: 27-55.

24. Islam MR, Nagao JI, Zendo T, Sonomoto K. 2012. Antimicrobial mechanism of lantibiotics", Biochem. Soc. Trans. 40: 1528-1533.

25. Punyaunppa-path S, Phumkhachorn $P$, Rattanachaikunsopon P. 2015. Nisin: production and mechanism of antimicrobial action. Int. J. Curr. Res. Rev. 7: 47-53.

26. Bauer R, Dicks LMT. 2005. Mode of action of lipid IItargeting lantibiotics. Int. J. Food Microbiol. 101: 201-216.

27. Halo H, Jeknic Z, Daeschel M, Stevanovic S, Nes IF. 2001. Plantaricin $\mathrm{W}$ from Lactobacillus plantarum belongs to a new family of two-peptide lantibiotics. Microbiology 147: 643-651.

28. Li L, Shi Y, Cheserek MJ, Su G, Le G. 2013. Antibacterial activity and dual mechanisms of peptide analog derived from cell penetrating peptide against Salmonella typhimurium and Streptococcus pyogenes. Appl. Microbiol. Biotechnol. 97: 1711-1723.

29. Ibrahim HR, Sugimoto Y, Aoki T. 2000. Ovotransferrin antimicrobial peptide (OTAP-92) kills bacteria through a membrane damage mechanism. Biochim. Biophys. Acta 1523: 196-205.

30. Raybaudi-Massilia RM, Mosqueda-Melgar J, Soliva-Fortuny R, Martın-Belloso O. 2009. Control of pathogenic and spoilage microorganisms in fresh-cut fruits and fruit juices by traditional and alternative natural antimicrobials. Compr. Rev. Food Sci. Food Saf. 8: 157-180.

31. López Camelo AF, Gómez PA. 2004. Comparison of color indexes for tomato ripening. Hortic. Bras. 22: 534-537.

32. Okuku DO, Fett WF. 2004. Effect of nisin in combination with EDTA, sodium lactate, and potassium sorbate for reducing Salmonella on whole and fresh-cut cantaloupe. J. Food Prot. 67: 2143-2150.

33. Ghosh A. 2009. Identification of microorganisms responsible for spoilage of tomato (Lycopersicon esculentum) fruit. J. Phytol. 1: $414-416$ 